\title{
THERMAL PERFORMANCE ANALYSIS OF A STIRLING ENGINE ENERGIZED WITH EXHAUST GAS OF A DIESEL ENGINE
}

\author{
Mesut DUZGUN* and Halit KARABULUT** \\ Department of Automotive Engineering, Faculty of Technology, Gazi University, 06560, Ankara, Turkey \\ *mduzgun@gazi.edu.tr; ORCID: 0000-0003-0582-4183 \\ ${ }^{* * *}$ halitk@gazi.edu.tr; ORCID: 0000-0001-6211-5258
}

(Geliş Tarihi: 03.05.2021, Kabul Tarihi: 11.10.2021)

\begin{abstract}
Theoretical and experimental investigations indicate that at high loads such as 3/4 throttling or more and high speeds such as $3000 \mathrm{rpm}$ or more, the exhaust gas temperatures of the Internal Combustion engines are about 900 $1000 \mathrm{~K}$. The amount of heat wasted with exhaust gas of the Internal Combustion engines is equivalent to the power of them. By considering this feature of the Internal Combustion engines, a Hybrid engine consisting of an Internal Combustion (IC) engine and a gamma type Stirling engine was proposed and analyzed from the thermodynamic point of view. Hybrid engine is formed by combining the Stirling and IC engines via a common crankshaft and a common cylinder. The Internal Combustion engine may be a four stroke Diesel engine having an unconventional piston consisting of a crown and a rod. Via using this kind of pistons, two chambers are created in the same cylinder where one of them take part at above of the piston crown, while the other is taking part at below of the piston crown. In the combined engine presented here, the chamber at below of the piston crown is used as the expansion volume of the Stirling engine while the other chamber is being used as operational volume of the Diesel engine. In this study the thermodynamic performance of the Hybrid engine was investigated via using statistical values of common Diesel engines. For Stirling engine; $800 \mathrm{~K}$ heater surface temperature, $392 \mathrm{~K}$ cooler surface temperature, $800 \mathrm{~W} / \mathrm{m}^{2} \mathrm{~K}$ heat transfer coefficient in regenerator, $300 \mathrm{~W} / \mathrm{m}^{2} \mathrm{~K}$ heat transfer coefficient in cooler and heater, $250 \mathrm{rad} / \mathrm{s}$ engine speed and 12.5 bar air charging pressure were used as principal inputs. The output power of the Diesel engine was assumed to be $120 \mathrm{~kW}$ which provides $120 \mathrm{~kW}$ heat to Stirling engine. The heat transfer areas of cooler, heater and regenerator were optimized as $0.33 \mathrm{~m}^{2}, 0.6 \mathrm{~m}^{2}$ and $4.6 \mathrm{~m}^{2}$ respectively. The optimum thermal efficiency and power of the Stirling engine were determined as $47 \%$ and $24 \mathrm{~kW}$. The total thermal efficiency of the combined engine is expected to increase $6 \%$ compared to the stand-alone Internal Combustion engine. For 12.5 bar average gas pressure in the cylinder of Diesel engine, the working fluid mass in the Stirling engine was determined as $17 \mathrm{~g}$.
\end{abstract}

Keywords: Energy Source, Heat Recovery, Thermodynamic Analysis, Hybrid engine, Combined Stirling and Diesel engine.

\section{BİR DİZEL MOTORUNUN EGZOZ GAZI ILLE ENERJILENDIRILEN STIRLING MOTORUNUN ISIL PERFORMANS ANALIZLERI}

Özet: Teorik ve deneysel birçok araştırma içten yanmalı motorlarda 3/4 ve daha fazla gaz kelebek açıklığında, $3000 \mathrm{rpm}$ ve daha yüksek devirlerde egzoz gazı sıcaklığının 900-1000 K'e ulaştı̆ıını göstermektedir. İçten yanmalı motorlarda egzoz gazı ile atılan ısı yaklaşık olarak motorların güçlerine eşit miktardadır. İçten yanmalı motorların bu özellikleri göz önünde bulundurularak, bu çalışmada içten yanmalı bir motor ve bir stirling motorundan meydana gelen hibrit bir motorun termodinamik analizlerinin yapılması amaçlanmıştı. Bu hibrit motor; içten yanmalı motor ile stirling motorunun krank mili ve silindirinin ortak kullanımı ile meydana gelmektedir. İçten yanmalı motor geleneksel olmayan bir piston ve biyel mekanizmasından oluşan 4 zamanlı bir dizel motordur. Bu tip pistonlar kullanılarak aynı silindir içerisinde biri piston tepesinin üstünde diğeri pistonun alt tarafinda olmak üzere iki oda oluşturulmaktadır. Bu çalışmada sunulan hibrit motorda pistonun altında kalan hacim stirling motorun genleşme hacmi olarak kullanılırken diğer oda dizel motorun çalışma hacmi olarak kullanılmaktadır. Bu çalışmada yaygın kullanımda olan bir dizel motorunun istatistiksel verileri kullanılarak stirling motorunun termodinamik performansı incelenmiştir. Stirling motoru için analiz girdileri olarak; $800 \mathrm{~K}$ ssıtıcı yüzey sıcaklığı, $392 \mathrm{~K}$ soğutucu yüzey sıcaklığı, $800 \mathrm{~W} / \mathrm{m}^{2} \mathrm{~K}$ rejeneratörün 1 sı transfer katsayısı, $300 \mathrm{~W} / \mathrm{m}^{2} \mathrm{~K}$ 1sitıc1 ve soğutucunun 1sı transfer katsayısı, $250 \mathrm{rad} / \mathrm{s}$ motor hızı ve 12.5 bar hava şarj basıncı kullanılmışır. Dizel motorunun çıkış gücünün $120 \mathrm{~kW}$ olduğu varsayılarak Stirling motoru için de $120 \mathrm{~kW}$ 'lık giriş sıcaklık değeri kabul edilmiştir. Soğutucu, 1sitıcı ve rejeneratörün 1sı transfer alanları sırası ile $0,33 \mathrm{~m}^{2}, 0,6 \mathrm{~m}^{2}$ ve $4,6 \mathrm{~m}^{2}$ olarak optimize edilmiştir. Stirling motorunun optimum termal verimliliği ve motor gücü $\% 47$ ve $24 \mathrm{~kW}$ olarak belirlenmiştir. Hibrit motorun toplam termal verimliliği yalnız içten yanalı motorun sağladığı değer ile karşılaştırıldığında \%6 artmıştır. Dizel motorun silindi içerisindeki ortalama gaz basıncının 12,5 bar olduğu durumda Stirling motorundaki çalışma akışkanının kütlesi $17 \mathrm{~g}$ olarak belirlenmiştir.

Anahtar Kelimeler: Enerji kaynağı, Isı geri kazanımı, Termodinamik analiz, Hibrit motor, Birleştirilmiş Dizel ve Stirling motoru 


\section{NOMENCLATURE}

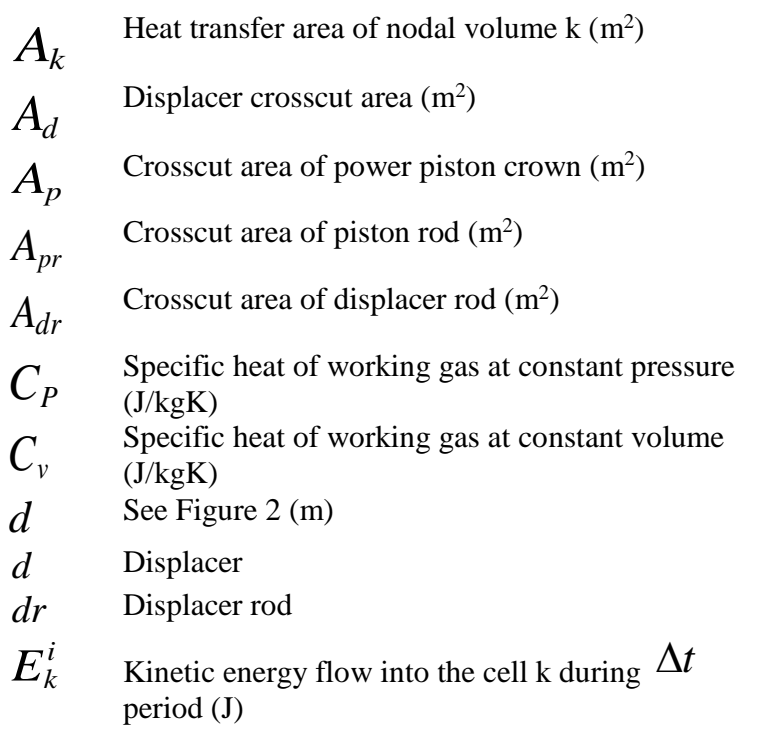

$E_{k}^{o} \quad$ Kinetic energy flow out of the cell k during $\Delta t$ period $(\mathrm{J})$

$f \quad$ See Figure $2(\mathrm{~m})$

F $\quad$ Former

$H_{k}^{i} \quad$ Enthalpy follow into the cell k during $\Delta t$ period (J)

$H_{k}^{o} \quad$ Enthalpy follow out of the cell k during $\Delta t$ period $(\mathrm{J})$

$h \quad$ See Figure $2(\mathrm{~m})$

$i \quad$ Into the cell $\mathrm{k}$

$k \quad$ Cell counter

$L \quad$ Left to the cell k

$m \quad$ Total gas mass in the engine $(\mathrm{kg})$

$m_{k} \quad$ Air mass in cell $\mathrm{k}(\mathrm{kg})$

$m_{k}^{F} \quad$ Air mass in cell $\mathrm{k}$ at former time step $(\mathrm{kg})$

$m_{k}^{R} \quad$ The total air mass in cells on the right of the cell k $m_{k} \quad(\mathrm{~kg})$

$m_{k}^{L} \quad$ The total air mass in cells on the left of the cell $\mathrm{k}$ $(\mathrm{kg})$

$\Delta m_{k} \quad$ Change of mass in cell k during the period $\Delta t$ (kg)

$o \quad$ Out of the cell k

$p \quad$ Pressure in the engine (bar)

p Piston

pr Piston rod

$R \quad$ Crank radius (m)

$R \quad$ Right to the cell k

$\mathfrak{R}$ Gas constant of working fluid $(\mathrm{J} / \mathrm{kgK})$

$S_{p} \quad$ Length of the piston rod (m)

$S_{d} \quad$ Length of the displacer rod (m)

$T_{k} \quad$ Gas temperature in cell $\mathrm{k}(\mathrm{K})$

$T_{k}^{w} \quad$ Matrix temperature in cell k (K)

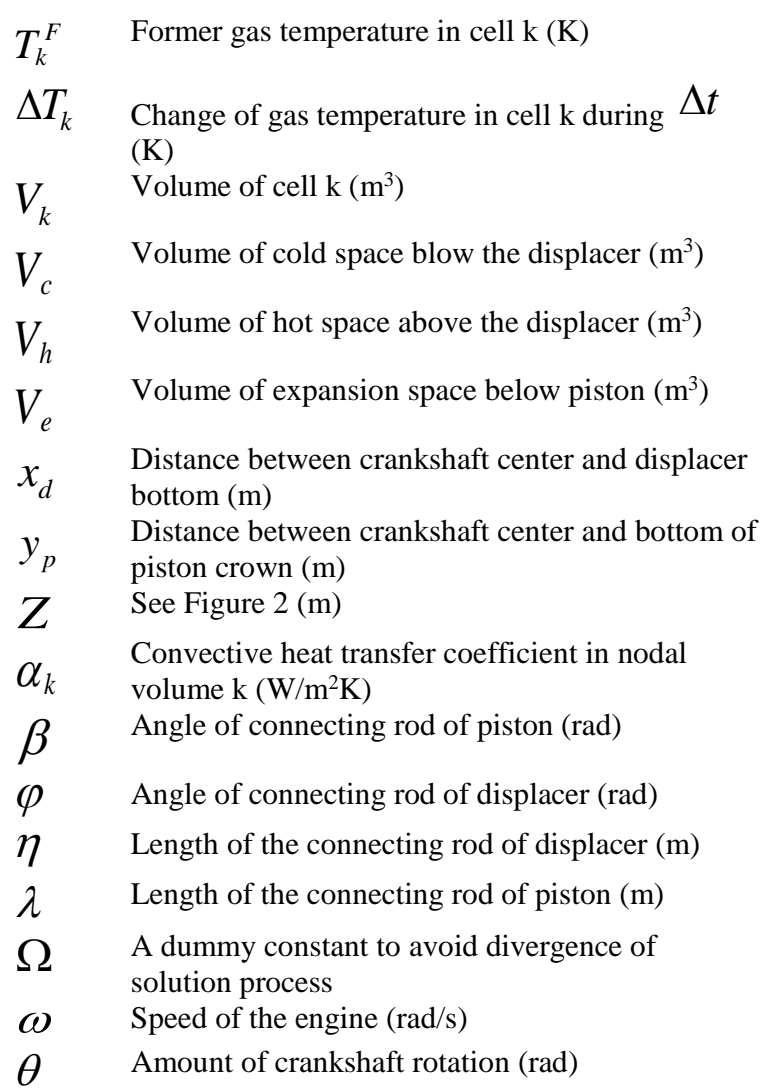

\section{INTRODUCTION}

Stirling engine is a technology that can be used to convert alternative energies into mechanical energy. Stirling engine is also eligible to improve the performance of the current energy conversion systems by hybridizing them with the Stirling engine. However, the current level of the Stirling technology is not sufficient to use them in industrial energy conversion systems. For the current situation at least forty research teams are working on Stirling engines. Some of the recent research is presented in the following review of the literature.

For the time being, most of the transport and work machines use piston type Internal Combustion Engines. The largest portion of the petroleum produced in the world is consumed by the piston type Internal Combustion Engines named as gasoline and Diesel. By these engines, only $30-40 \%$ of the heat generated by combustion is converted to mechanical energy.

The remaining of the heat is wasted to the atmosphere by exhaust gas and cooling water. The ratios of the heat wasted by exhaust gas to the total energy of the fuel is approximately $30 \%$. The ratio of the cooling heat to the total energy of the fuel is also at the same order with exhaust energy. In order to recover the waste heat of exhaust gas, different concepts are implemented. Among them the most commons are the use of turbocharger, thermoelectric generator, Stirling engines and Rankin 
Cycle Engines (Jadhao and Thombare, 2013; Noor et al, 2014).

Stirling engines are thermodynamic systems converting the heat into mechanical power via a thermodynamic cycle. For the time being, the use of Stirling engines in an exhaust heat recovery system is a concept. In order to recover the exhaust heat of an Internal Combustion Engine by means of a Stirling engine, some alternative methods are available. One of them may be the energization of an autonomous Stirling engine with the exhaust gas of an autonomous Internal Combustion Engine where no mechanical link is present between Stirling engine and Internal Combustion Engine. Another method may be the mechanical combination of a Stirling engine with an Internal Combustion engine by means of a common crankshaft. The other method may be the energization of a Free piston Stirling engine with the exhaust gas of an Internal Combustion Engine, where no mechanical link is present between the Free piston Stirling engine and Internal Combustion Engine. A forth method may be the mechanical combination of a gamma type Stirling engine and an Internal Combustion Engine via a common crankshaft and a common cylinder. According to the literatures of Stirling and Internal Combustion Engines, there is not any successful application of Stirling engines in exhaust heat recovery systems. There are however some attempts to use Stirling engines as a heat recovery system on Internal Combustion Engines. There are also several theoretical analyses related to the performance prediction of Stirling engines using exhaust gas as energy source.

Hirata and Kawada (2005) conducted a project to develop a multi cylinder and large power Stirling engine for use as prime-mover on ships. Theoretical analysis and experimental data obtained from a three-cylinder Stirling engine prototype indicated that the size of Stirling engines is not appropriate for ship propulsion. Authors pointed out however that, Stirling engine can be used together with ship Diesel engines as a heat recovery device.

Li et al (2012) performed a rhombic-drive Stirling engine development project for Micro Combined Heat and Power systems. The developed Stirling engine works with exhaust gases at moderate and high temperatures. The heater of the Stirling engine was housed in a chamber where the heater, consisting of tubes, makes heat exchange with an exhaust gas circulating at high turbulence. The exhaust gas circulating in the chamber comes from a gasoline engine. The developed engine provides $3476 \mathrm{~W}$ power at $1248 \mathrm{rpm}$ speed. The heat requirement of the Stirling engine was estimated to be $15000 \mathrm{~W}$. According to the presented data, the thermal efficiency of the engine is $23 \%$ while the heater temperature is about $850 \mathrm{~K}$.

Karabulut et al (2019) proposed a Martini type Stirling engine working with exhaust energy of an Internal Combustion Engine with $100 \mathrm{~kW}$ power output and analyzed its thermodynamic performances. For realistic conditions, the power output and thermal efficiency of the Martini Engine was predicted as about $10 \mathrm{~kW}$ and $21 \%$ respectively. Martini Engine was found to be an efficient device for exhaust heat recovery. In order to determine the optimum type Stirling engines for recovering of heats with low and moderate temperatures, Wang and coworkers (Wang et al, 2016) conducted a comprehensive literature survey. Authors concluded that the kinetic and thermoacoustic type of Stirling engines are more suitable for the recovery of the low and moderate temperature heats.

Alfarawi et al (2014) carried out a theoretical study to estimate the mass and volume of a $2 \mathrm{~kW}$ Stirling engine energized by the exhaust gas heat of an Internal Combustion Engine. The engine was considered to drive the alternator which will be decoupled from the Internal Combustion Engine. The hot and cold end temperatures of the engine were assumed to be 850 and $450 \mathrm{~K}$. The charge pressure, rotation speed, regenerator volume, compression swept volume and expansion swept volume were estimated as $2 \mathrm{MPa}, 750 \mathrm{rpm}, 540 \mathrm{cc}, 611 \mathrm{cc}$ and $814 \mathrm{cc}$ respectively. The engine is expected to provide $40 \%$ thermal efficiency. The heater and cooler of the engine were optimized with CFD analysis. The mass of the engine was predicted as about $11-14 \mathrm{~kg}$.

In a theoretical Study, Izadiamoli and Sayyaadi (2018) conducted performance analysis of a hybrid power system consisting of an Otto Engine and a Stirling engine. In the same study Izadiamoli and Sayyaadi (2018) conducted the performance analysis of a hybrid power and cooling system consisting of an Otto Engine, A Stirling engine and A Stirling Cooler. In the study, authors predicted the exhaust gas temperature of the Otto Engine via Finite Speed and Finite Time Thermodynamics. The performance analyses of the Stirling engine and Stirling Cooler were carried out via a second order thermodynamic model. Under full load, the exhaust gas temperature of the Otto Engine was determined to be varying between $975 \mathrm{~K}$ and $1060 \mathrm{~K}$ as the engine speed varying from $1000 \mathrm{rpm}$ to $6000 \mathrm{rpm}$. While the thermal efficiency of the stand-alone Otto Engine was about $30 \%$, the thermal efficiency of the combined Otto-Stirling power system reached to $36 \%$. For the combined power and cooling system authors reported a $15 \%$ total fuel saving as well as $27 \%$ reduction in carbon dioxide production.

Yu et al (2013) conducted a theoretical study to design a Stirling engine working with the exhaust gas of a 1.5 Liter four cylinders gasoline engine which is a turbocharged engine having $70 \mathrm{~kW}$ power output at economic use speed. Initially, authors investigated the exhaust gas temperature of the gasoline engine. For this purpose, authors measured the inlet and outlet gas temperatures of the turbocharger. The temperature measurements were conducted at full load. For the speed range of 2000-3500 rpm, the inlet and outlet gas temperatures of the turbocharger were found to be about $930{ }^{\circ} \mathrm{C}$ and $800{ }^{\circ} \mathrm{C}$. In the design of the Stirling engine, the outlet gas temperature of the turbocharger was used. 
Hydrogen was chosen as working fluid for Stirling engine. The power and thermal efficiency of the designed Stirling engine were reported as $6475 \mathrm{~W}$ and $17.5 \%$. According to this results, the total thermal efficiency of the combined Otto/Stirling system is expected to increase $10 \%$ compared to that of the standard Otto Engine.

Via developing a second order thermodynamic model, Saxena and Ahmed (2017) carried out the performance analyses of a rhombic-drive Stirling engine working with exhaust gas heat. Authors examined the performance of the engine according to several design parameters like; working fluid mass, total dead volume, thermal resistance, and hot side and cold side temperatures. For $1 \mathrm{~kW}$ power output, in the case of using tube-fin type compact heat exchangers, authors predicted a 7.8 liter total working fluid volume and $12.6 \%$ thermal efficiency. For the same power output, in the case of using printed circuit heat exchangers, authors predicted a 3.25 liter total working fluid volume and $10.8 \%$ thermal efficiency.

Via the zero order, first order and second order thermodynamic analyses, Cullen et al (2009) investigated the power and thermal efficiency of an engine named as United Stirling 4-95 Mk II, which is considered as the heat recovery component of an Otto Engine having 255 $\mathrm{kW}$ power output, $763 \mathrm{~K}$ exhaust gas temperature and $351 \mathrm{~K}$ cooling water temperature. United Stirling 4-95 II is a double acting 4-cylinder alpha type engine having $540 \mathrm{cc}$ swept volume. As working fluid, the engine uses hydrogen at $20 \mathrm{MPa}$. For $993 \mathrm{~K}$ expansion volume gas temperature, $323 \mathrm{~K}$ coolant temperature and $1800 \mathrm{rpm}$ speed; the rated power of the United Stirling 4-95 II is given as $25 \mathrm{~kW}$. By considering that the United Stirling 4-95 II uses the exhaust gas as heat source and cooling water as heat sink (which are provided by the above mentioned Otto Engine), authors predicted $48 \mathrm{~kW}$ power at $4000 \mathrm{rpm}$ speed for United Stirling 4-95 II. For this power and speed, the thermal efficiency of United Stirling 4-95 II was predicted to be about $30 \%$. The thermal efficiency of the combined Otto/Stirling system was estimated as $42.2 \%$ where the thermal efficiency of the stand-alone Otto Engine was about $35.5 \%$.

In order to indicate that whether the Stirling engine has a potential of use for recovering heat from exhaust gas of Otto cycling engines, Huang et al (2016) conducted an experimental and theoretical study. In the study authors measured the exhaust gas temperature of an Otto Engine having $110 \mathrm{~kW}$ rated power. Via using the measured exhaust gas temperature as the heat source temperature of a beta type rhombic-drive Stirling engine, authors calculated the shaft power of the Stirling engine. The exhaust gas temperature of the Otto Engine was measured as about $950 \mathrm{~K}$. The shaft power of the Stirling engine was predicted as $1.4 \mathrm{~kW}$ with adiabatic second order thermodynamic model. However, the experimental investigation indicated that the power generated by the Stirling engine is about $535 \mathrm{~W}$ only. As the result of the study authors pointed out that, the heat transfer coefficient between the exhaust gas and heater of the Stirling engine is very low. Authors pointed out also that, the adiabatic thermodynamic model is not a realistic tool to calculate the performance parameters of Stirling engines. Despite of some problems, Stirling engine was found to be a promising technology for heat recovery from exhaust gas of Internal Combustion Engines.

In this study a Hybrid engine concept consisting of an Internal Combustion Engine and a Gamma Type Stirling engine was proposed. The Stirling component of the Hybrid engine works with the exhaust gas energy of the IC component. The energy and temperature of the exhaust gas ejected by IC Engine is assumed to be statistically known and the thermal performance of the Stirling engine was investigated via the nodal analysis. The main novality of this work is the mechanical combination of a gamma type Stirling engine and an Internal Combustion Engine via a common crankshaft and a common cylinder.

\section{PHYSICAL SYSTEM AND MATHEMATICAL MODEL}

\section{Physical system}

Figure 1 indicates the schematic view of the combined Stirling and Internal Combustion (IC) engine. The combined engine involves rectangularly connected two cylinders which are named as displacer cylinder and power cylinder. As seen in Figure 1, the volume of the displacer cylinder is divided into two chambers by a displacer. Chambers above and below the displacer are named as hot and cold volumes respectively. The volume above the displacer is connected to the volume below the displacer through a heater, a regenerator and a cooler. Heater is a heat exchanger where the working fluid of the Stirling engine makes heat exchange with the exhaust gas of the IC engine. The regenerator is a cavity filled with a porous material such as wire screen foils or randomly packed fibrous metallic materials. The solid part of the regenerator is named as regenerator matrix. The cooler is also a heat exchanger in which the working fluid of the Stirling engine makes heat exchange with a cold fluid.

In the system a power piston, similar to that of the two stroke marine engines, is used. Via this piston, two chambers are facilitated in the cylinder of the IC engine; one of them is above the crown of the piston while the other is below the crown. The volume below the crown is connected to the displacer cylinder and enables the expansion of the working fluid of the Stirling engine. The volume above the crown is the operational volume of the IC engine where the intake, compression, combustion, expansion and exhaust processes of the IC engine are accomplished. Between volumes below and above the crown, there will be a certain amount of gas leakage. Therefore, the working fluid of the Stirling engine may not be special fluid such as Helium or Hydrogen. As seen from Figure 1, the crankshaft has only 1 crankpin and, connecting rods of both the power piston and displacer are connected to this crankpin. 
The thermodynamic cycle of the Stirling engine may be explained by dividing the circle formed by crankpin into 4 sections as illustrated in Figure 1. The Position of the crankpin seen in Figure 1 may be assumed as the starting instant of the engine. While the crankpin is at $\mathrm{A}$, the power piston is at the bottom dead center of itself. The displacer is at the bottom dead center of itself as well. The total inner volume of the Stirling engine is at lowest level. The most of the working fluid of Stirling engine is in hot volume of the displacer cylinder. Therefore, the pressure of the working fluid of Stirling engine is at highest level. While the crankpin is moving from A to B, the displacer remains at about the bottom dead center of itself. The power piston moves upwards and the expansion volume below the crown enlarges. During this process, the working fluid in the hot volume of displacer cylinder flows into the expansion volume and generates work. When the crankpin arrived to $\mathrm{B}$, the expansion period of the Stirling engine terminates. A significant amount of the working fluid of the Stirling engine is in the hot volume above the displacer. The other significant amount of the working fluid is in the expansion volume below the power piston. While the crankpin is mowing from $\mathrm{B}$ to $\mathrm{C}$, the power piston remains at about the top dead center of itself. The displacer moves upwards and removes the working fluid from the hot volume to the cold volume. During this process the total inner volume of the Stirling engine remains almost constant and the working fluid undergoes a constant volume cooling process by making heat exchange with regenerator and cooler through narrow flow channels and generates a damping force acting to displacer. The flow resistance appearing in the heater regenerator and cooler may also generate adequate damping force to stabilize the motion of the displacer.

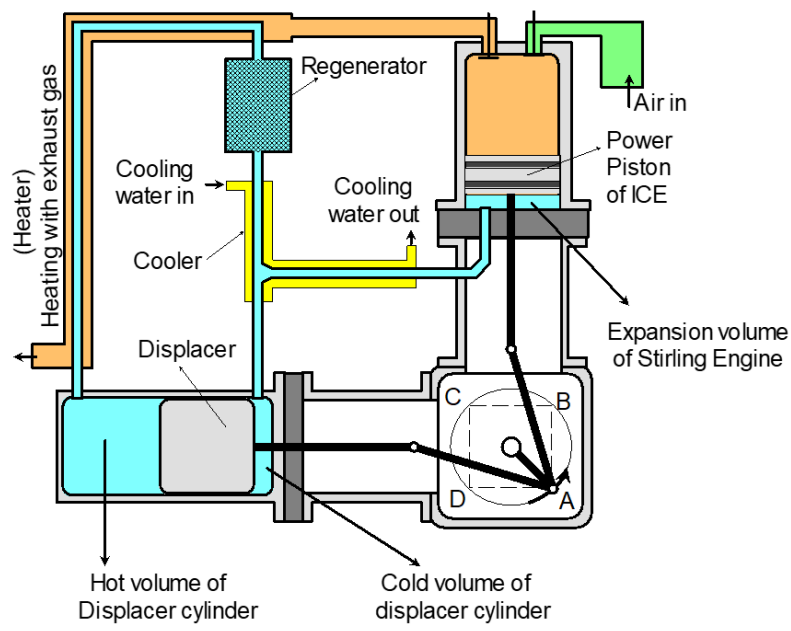

Figure 1. Schematic view of the conceptual Hybrid engine.

When the crankpin arrived to $\mathrm{C}$, the total inner volume of the Stirling engine is almost at maximum level and the gas pressure in the engine is at minimum level. A significant amount of the working fluid is in the expansion volume below the crown of the piston. While the crankpin is moving from $\mathrm{C}$ to $\mathrm{D}$, the displacer remains almost constant at about the top dead center of itself. The power piston moves downwards and removes the working fluid from expansion volume to the cold volume below the displacer through a cold heat exchanger. During this process the working fluid undergoes a compression process. Due to the compression work made on the working fluid, the temperature of it tends to increase. However, the heat exchange in the cold heat exchanger limits the increase of the working fluid partially. When the crankpin arrived to $\mathrm{D}$, the largest amount of the working fluid is collected in the cold volume below the displacer. Due to that the temperature of the working fluid is comparatively lower, its pressure is also comparatively lower. While the crankpin is moving from $\mathrm{D}$ to $\mathrm{A}$, the power piston remains almost constant at about the bottom dead center of itself. The displacer moves downwards and removes the working fluid from cold volume to the hot volume through cooler, regenerator and heater. During this process the total inner volume of the Stirling engine remains almost the same. While the working fluid is flowing from the cold volume to the hot volume, it makes heat exchange at constant volume with regenerator and heater. This process is the heating process of the working fluid at constant volume. Due to increase of the temperature, the pressure of the working fluid increases as well. When the crankpin arrived to $\mathrm{A}$, the thermodynamic cycle of the Stirling engine is completed. The working fluid is ready to perform a second cycle.

In gamma type Stirling engines, the connection of displacer cylinder to expansion volume may be either from hot end or cold end. Despite that the hot end connection provides a relatively higher work, in this study the cold end connection was preferred. This is done to protect the expansion volume from high temperature. The lower expansion volume temperature should prevent evaporation of lubricant and protect the heat exchangers from contamination of lubricant.

\section{Mathematical Model}

The analysis conducted here involves the prediction of performance parameters of the Stirling component of combined engine. In the analysis, the nodal approximation was used. The inner volume of the Stirling engine was divided into 28 nodal volumes or cells. The first and second of nodal volumes are the hot volume of the displacer cylinder and the heater volume. Nodal volumes from 3 to 25 are regenerator cells. Nodal volumes 26,27 and 28 are respectively; cooler volume, cold volume of the displacer cylinder and expansion volume below the crown of the piston.

The unknowns of this analysis are; the temporal gas pressure in the engine (p), the temporal nodal temperatures of the gas $\left(\mathrm{T}_{\mathrm{k}}\right)$, the temporal values of the varying nodal volumes $\left(\mathrm{V}_{\mathrm{k}}\right)$ and the temporal masses in nodal volumes $\left(\mathrm{m}_{\mathrm{k}}\right)$.

Assumptions of the analysis are;

1) The independent variable of the analysis is time (t). 
2) The working fluid of Stirling engine is air and it is assumed to be a perfect gas.

3) Pressure differences between different nodal volumes due to flow frictions are disregarded.

4) For regenerator matrix no energy balance is used.

5) The regenerator matrix possesses a permanent temperature distribution varying step by step between cooler and heater temperatures.

6) The analysis does not involve the calculation of heat transfer between exhaust gas and outer surface of heater.

7) The inner heat transfer surface temperatures of cooler and heater are the known parameters of the analysis.

8) The engine rotates with a constant speed.

9) In all nodal volumes, there is heat exchange between working gas and solid boundaries.

The instantaneous values of the gas pressure in the engine was calculated with the Schmidt formula given as

$$
p=\frac{m \Re}{\frac{V_{1}}{T_{1}}+\frac{V_{2}}{T_{2}}+\ldots+\frac{V_{28}}{T_{28}}}
$$

The variations of temporal temperature in nodal volumes were calculated with the first law of the thermodynamics given for unsteady open systems,

$$
Q_{k}-W_{k}=\left(m_{o} \cdot h_{o}\right)_{k}-\left(m_{i} \cdot h_{i}\right)_{k}+(\Delta U)_{k}
$$

In this equation;

$Q_{k}, W_{k},(\Delta U)_{k},\left(m_{o} \cdot h_{o}\right)_{k}$ and $\left(m_{i} \cdot h_{i}\right)_{k}$ indicate respectively the heat exchange of the working fluid with solid boundaries of the nodal volume, the work generated in the nodal volume, the internal energy variations in the nodal volume, the enthalpy conveyed out of the nodal volume and the enthalpy conveyed into the nodal volume. In Equation (2) by substituting

$$
\begin{aligned}
& Q_{k}=\alpha_{k} A_{k}\left(T_{k}^{w}-T_{k}\right) \Delta t \\
& W_{k}=p \Delta V_{k} \\
& (\Delta U)_{k}=m_{k} C_{v} \Delta T_{k}+C_{v} T_{k} \Delta m_{k} \\
& \left(m_{o} \cdot h_{o}\right)_{k}=H_{k}^{o} \\
& \left(m_{i} \cdot h_{i}\right)_{k}=H_{k}^{i}
\end{aligned}
$$

the equation

$$
\begin{aligned}
& \alpha_{k} A_{k}\left(T_{k}^{w}-T_{k}\right) \Delta t-p \Delta V_{k}= \\
& H_{k}^{o}-H_{k}^{i}+m_{k} C_{v} \Delta T_{k}+C_{v} T_{k} \Delta m_{k}
\end{aligned}
$$

is obtained. By adding $\Omega \Delta T_{k}$ to both sides of the last equation and then solving for $\Delta T_{k}$ results in
$\Delta T_{k}=\left[\begin{array}{l}\alpha_{k} A_{k}\left(T_{k}^{w}-T_{k}\right) \Delta t-p \Delta V_{k}+ \\ \left(H_{k}^{i}-H_{k}^{o}\right)-C_{v} T_{k} \Delta m_{k}+\Omega \Delta T_{k}\end{array}\right] /\left(m_{k} C_{v}+\Omega\right)$

In last equation, the subscript $\mathrm{k}$ indicates any one of the nodal volumes taking part in the engine. The term $\left(H_{k}^{i}-H_{k}^{o}\right)$

indicates the total enthalpy flow in and out of the nodal volume $\mathrm{k}$. When the engine is running, the working fluid may enter in to the nodal volume $\mathrm{k}$ from the nodal volume $\mathrm{k}-1$ and, exit towards nodal volume $\mathrm{k}+1$. It may also enter from the nodal volume $\mathrm{k}+1$ and, exit towards nodal volume $\mathrm{k}-1$. There are also other specific situations such as entering and exiting through the same boundary etc. If the enthalpy flow in and out of the nodal volume $\mathrm{k}$ is calculated by using the boundary temperatures of the nodal volume $\mathrm{k}$, the complexity of calculation is avoided and its calculation simply becomes,

$$
\left(H_{k}^{i}-H_{k}^{o}\right)=\left[\begin{array}{l}
-C_{p} \frac{T_{k}+T_{k+1}}{2} \sum_{j=k+1}^{j=n} \Delta m_{j} \\
-C_{p} \frac{T_{k-1}+T_{k}}{2} \sum_{j=1}^{j=k-1} \Delta m_{j}
\end{array}\right]
$$

The total of mass variations in volumes on the right and in volumes on the left of $\mathrm{k}$ are calculated as,

$$
\sum_{j=k+1}^{j=n} \Delta m_{j}=\left[\begin{array}{l}
\left(m_{k+1}+m_{k+2}+m_{k+3}+\ldots+m_{n}\right)- \\
\left(m_{k+1}^{F}+m_{k+2}^{F}+m_{k+3}^{F}+\ldots+m_{n}^{F}\right)
\end{array}\right]
$$

and

$$
\sum_{j=1}^{j=k-1} \Delta m_{j}=\left[\begin{array}{l}
\left(m_{1}+m_{2}+\ldots+m_{k-1}\right)- \\
\left(m_{1}^{F}+m_{2}^{F}+\ldots+m_{k-1}^{F}\right)
\end{array}\right]
$$

The temporal values of the gas temperatures in cells are calculated by taking the sum of temperature change of gas and the former value of its temperature such as,

$T_{k}=T_{k}^{F}+\Delta T_{k}$

In last equation $T_{k}$ and $T_{k}{ }^{F}$ indicate respectively the temporal temperatures of the cell at the current and at the previous time steps.

The temporal values of the varying volumes are calculated via kinematic relations. The coordinate system and some of symbols used in the analysis are seen in Figure 2. The crankshaft center was chosen as the origin of the coordinate system. The engine rotates in anticlockwise direction with a constant speed. As seen in Figure 2, the crankshaft angle was measured from negative direction of $\mathrm{y}$ axis. The power piston and 
displacer make reciprocal motions on $\mathrm{y}$ and $\mathrm{x}$ axes respectively. According to the position of the piston presented in Figure 2, the volume of expansion space of the Stirling engine, which takes part below the crown of the power piston, may be stated as

$$
V_{e}=\left(y_{p}-z\right)\left(A_{p}-A_{p r}\right)
$$

With respect to Figure 2, the position coordinate of the piston $\left(\mathrm{y}_{\mathrm{p}}\right)$, may be stated as

$$
y_{p}=-R \cos \theta+\lambda \cos \beta+S_{p}
$$

As seen in Figure 2, $\beta$ is the angle between the axis of piston rod and its connecting rod. In terms of crankshaft angle $\beta$ is stated as,

$\beta=\arcsin \left[\frac{R}{\lambda} \sin \theta\right]$

According to the position of the displacer presented in Figure2, the volumes of the cold and hot spaces of the displacer cylinder may be stated respectively as

$$
V_{c}=\left(x_{d}-h\right)\left(A_{d}-A_{d r}\right)
$$

and

$$
V_{h}=\left(d-x_{d}-f\right) A_{d}
$$

With respect to Figure 2, the position coordinate of the displacer's bottom end may be stated as

$$
x_{d}=-R \sin \theta+\eta \cos \varphi+S_{d}
$$

As seen in Figure 2, $\varphi$ is the angle between displacer rod and its connecting rod and can be stated in terms of crankshaft angle as,

$$
\varphi=\arcsin \left(\frac{R}{\eta} \cos \theta\right)
$$

Temporal values of gas masses in nodal volumes are calculated with the perfect gas relation

$$
m_{k}=\frac{p V_{k}}{R T_{k}}
$$

Equations given above are adequate for the thermodynamic analysis of Stirling component of the combined engine.

For the solution of these equations a computer program was prepared in FORTRAN language. In the solution process, the crankshaft was assumed to be rotating with a constant speed of $\omega$. At the first instance of the solution process, the crankshaft angle was assumed to be $\theta=0$ and the initial positions of the power piston and displacer, $\mathrm{y}_{\mathrm{p}}$ and $\mathrm{x}_{\mathrm{d}}$, were determined. For this position of the piston and displacer, volumes of the all of cells were determined. After determination of the cell volumes, the temperatures of heat transfer surfaces in heater, regenerator and cooler were assessed. For heat transfer surfaces in heater, a uniform temperature may be assessed. For heat transfer surfaces in cooler, a uniform temperature may also be assessed. For regenerator matrix, a temperature profile varying step by step with equal increments may be assessed. That means, matrix temperatures in cells are uniform but, varies from cell to cell with equal increments. After completing assessment of the surface temperatures, the initial gas temperatures in cells were assessed. The most appropriate values for the initial gas temperatures in cells may be to set them equal to the surface temperatures of cells. After this, the initial gas pressure in the engine was calculated with Schmidt formula. After calculating the initial gas pressure in the engine, the initial air masses in cells were determined via Equation (21) and the determination of initial values were completed.

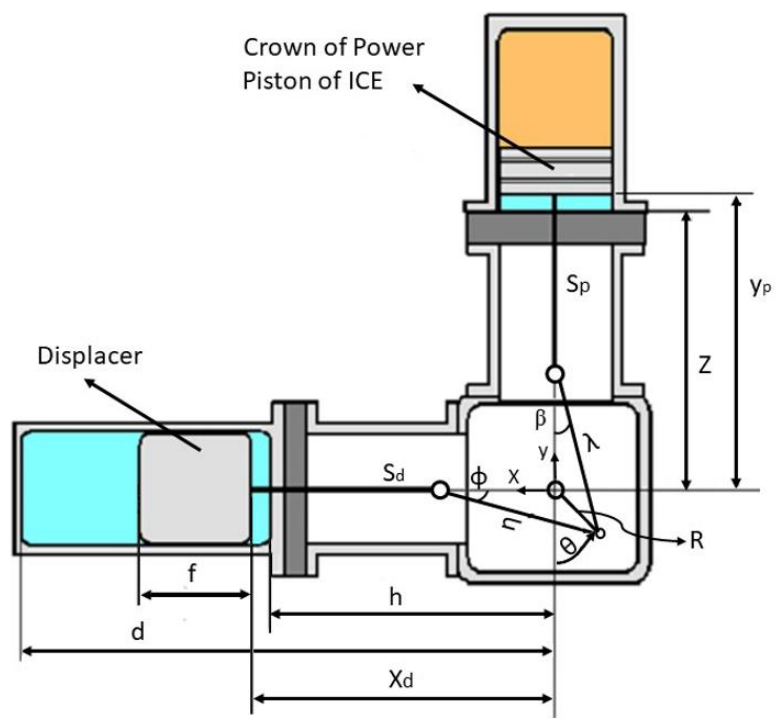

Figure 2. Symbols used in the analysis.

Then the crank shaft was rotated as $\Delta \theta=\omega \Delta t$. For this new position of crankshaft, volumes of cells were determined again. Via the Schmidt formula, by using the new cell volumes and the former cell temperatures and masses, the approximate gas pressure in the engine was predicted for the new position of the crankshaft. Then, by using the new cell volumes, new gas pressure and former gas temperatures in the general state equation of perfect gases, the approximate new values of the cell masses were determined. After this, the quantities defined by Equations (11) and (12) are calculated. Then, by introducing the quantities calculated with Equations (11) and (12) and former cell temperature into Equation (10), the approximate value of the enthalpy flow was determined. In order to predict the new approximate values of cell temperatures, initially temperature changes 
in cells were calculated via using Equation (10). After this, by using Equation (13), the new approximate temperatures of cells were calculated. In order to determine the precise values of new pressure, new cell temperatures and new cell masses, the calculations defined in this paragraph were iterated several times. Iteration number may be determined by observation. After reaching to stable values, not varying from iteration to iteration, the solution of equations was ended for the first time step. By rotating the crankshaft again as $\omega \Delta t$, the solution of equations for the second time step was initiated. The rest of the solution process is the repetition of the same operations for subsequent time steps.

When the simulation program is set to run, the cyclic quantities such as work, heat, average pressure etc., vary from cycle to cycle due to unsteady running of the simulation. The cyclic variations of cell temperatures and pressure are also not periodic curves. After a certain number of cycles, the transient running period of the simulation terminates and the steady running conditions are reached. At steady running conditions, the cyclic quantities such as work, heat, average pressure etc. do not vary from cycle to cycle. The cyclic variations of cell temperature and engine pressure becomes periodic curves.

In this simulation, since no energy balance equation is used for regenerator matrix, the cyclic heat exchange between gas and regenerator matrix may be not zero despite that it should be zero in a real engine. When introduced into the simulation program any values for heater area, cooler area and regenerator area; the cyclic work is correctly calculated. However, the cyclic heat transfers from heater to gas, the cyclic heat transfer from gas to cooler and the cyclic heat exchange between gas and matrix may not be calculated correctly because of unbalanced heat exchange with gas and regenerator matrix. Unless calculating the correct value of the heat transfer from heater to gas, the thermal efficiency of the engine may not be calculated correctly. In order to overcome with this difficulty, the cyclic heat exchange of the regenerator matrix is made zero by introducing proportional values for heater and cooler heat transfer areas. To find he proportional values of them, a trial and error operation is required. The flowchart of the thermodynamic analysis is shown in Figure 3.

\section{RESULTS AND DISCUSSION}

The air was used as working fluid and the thermodynamic performance of the Stirling component of the combined ICE-Stirling system was investigated. Table 1 indicates specific values used in the analysis of the Stirling engine and optimized inputs. In the solution of model equations, the appropriate magnitude of time steps was determined to be 0.00002 second. Adequately stable values of variables at any time step were obtained with 1000 iterations. The transient running period of the simulation was found to be minimum 300 cycles.
The inputs presented in Table 1 are determined considering the exhaust energy of a Diesel type IC Engine with $120 \mathrm{~kW}$ power at $2400 \mathrm{rpm}$ speed. Assuming that the economic running speed of Diesel engines is about $2400 \mathrm{rpm}$, the speed of the Stirling engine was set

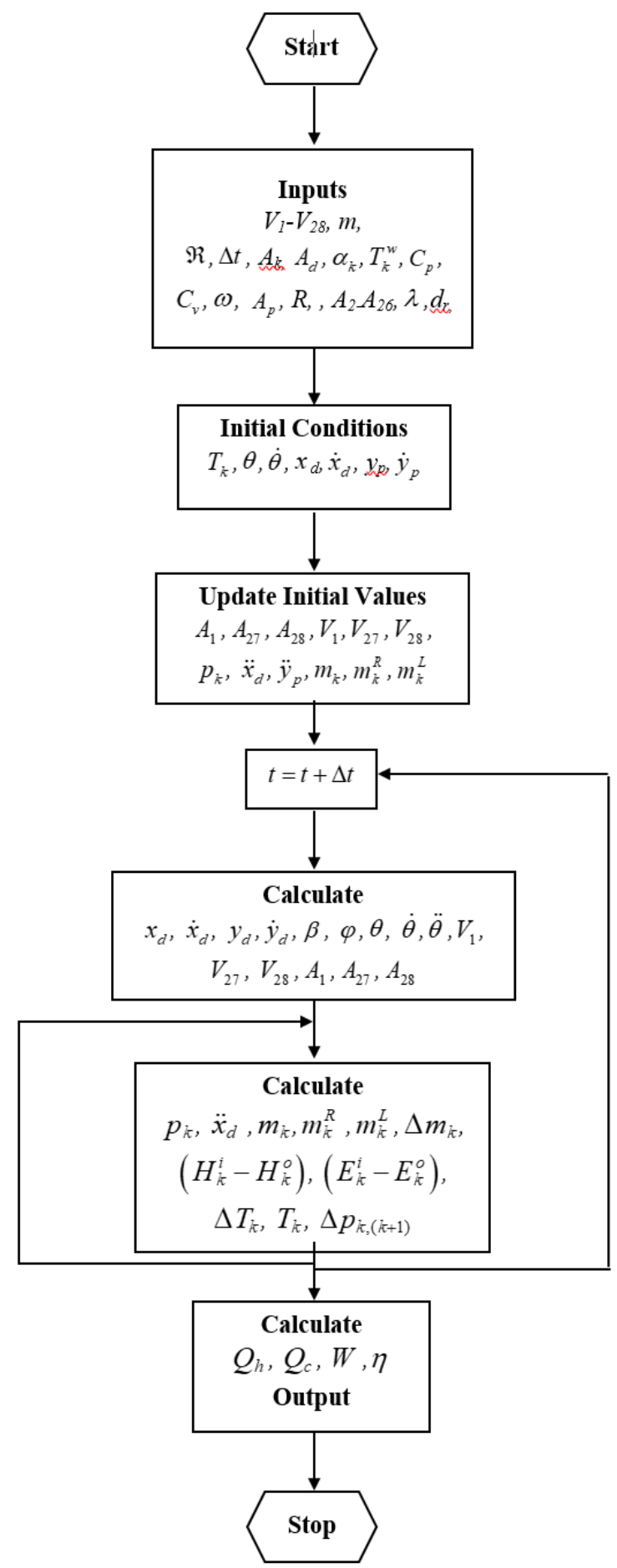

Figure 3. Thermodynamic analysis flowchart.

to $250 \mathrm{rad} / \mathrm{s}$ which corresponds to $2387 \mathrm{rpm}$. When optimizing the mass of the working fluid of the Stirling engine, the average pressure in the cylinder of the Diesel engine was used as a criterion. Since the expansion volume of the Stirling engine takes place below the crown of the piston of the Internal Combustion Engine, the average pressure of the Stirling cycle is dependent on 
the average cylinder pressure of the Internal Combustion engine. When the gas pressure of the IC engine exceeds the gas pressure of the Stirling engine, then some air leaks from operation volume of the IC engine into the expansion volume of the Stirling engine. When the gas

Table 1. Inputs used in the analysis.

\begin{tabular}{|c|c|c|}
\hline Names of Inputs & Symbol & $\begin{array}{l}\text { Numerical } \\
\text { value }\end{array}$ \\
\hline $\begin{array}{l}\text { Gas constant of working fluid } \\
(\mathrm{J} / \mathrm{kg} \mathrm{K})\end{array}$ & $\mathfrak{R}$ & 288 \\
\hline $\begin{array}{l}\text { Constant volume specific heat } \\
\text { of working gas }(\mathrm{J} / \mathrm{kg} \mathrm{K})\end{array}$ & $\mathrm{Cv}$ & 720 \\
\hline $\begin{array}{l}\text { Constant pressure specific heat } \\
\text { of working gas }(\mathrm{J} / \mathrm{kg} \mathrm{K})\end{array}$ & $\mathrm{Cp}$ & 1008 \\
\hline Optimum engine speed (rad/s) & $\omega$ & 250 \\
\hline Crank radius $(\mathrm{m})$ & $\mathrm{R}$ & 0.04 \\
\hline $\begin{array}{l}\text { Piston connecting rod length } \\
\text { (m) }\end{array}$ & $\lambda$ & $3.5 \mathrm{R}$ \\
\hline $\begin{array}{l}\text { Displacer connecting rod } \\
\text { length }(\mathrm{m})\end{array}$ & $\eta$ & $3.5 \mathrm{R}$ \\
\hline $\begin{array}{l}\text { Displacer cylinder crosscut } \\
\text { area }(\mathrm{m} 2)\end{array}$ & $A_{d}$ & $100 / 104$ \\
\hline $\begin{array}{l}\text { Power cylinder crosscut area } \\
\text { (m2) }\end{array}$ & $A_{p}$ & $100 / 104$ \\
\hline Piston rod crosscut area $(\mathrm{m} 2)$ & $A_{p r}$ & $2.5 / 104$ \\
\hline $\begin{array}{l}\text { Displacer rod crosscut area } \\
\text { (m2) }\end{array}$ & $A_{d r}$ & $2.5 / 104$ \\
\hline $\begin{array}{l}\text { Heat transfer coefficient in } \\
\text { regenerator }(\mathrm{W} / \mathrm{m} 2 \mathrm{~K})\end{array}$ & $\alpha_{k}$ & 800 \\
\hline $\begin{array}{l}\text { Heat transfer coefficient in } \\
\text { cooler and heater }(\mathrm{W} / \mathrm{m} 2 \mathrm{~K})\end{array}$ & $\begin{array}{l}\alpha_{26} \\
\alpha_{2}\end{array}$ & 300 \\
\hline $\begin{array}{l}\text { Surface temperature of heater } \\
(\mathrm{K})\end{array}$ & $T_{H}$ & 800 \\
\hline $\begin{array}{l}\text { Surface temperature of cooler } \\
(\mathrm{K})\end{array}$ & $T_{C}$ & 392 \\
\hline Heater heat transfer area $(\mathrm{m} 2)$ & $A_{2}$ & $6000 / 104$ \\
\hline Heater dead volume (m3) & $V_{2}$ & $300 / 106$ \\
\hline Cooler heat transfer area $(\mathrm{m} 2)$ & $A_{26}$ & $3300 / 104$ \\
\hline Cooler dead volume (m3) & $V_{26}$ & $165 / 106$ \\
\hline $\begin{array}{l}\text { Average heat transfer area in } \\
\text { hot volume of displacer } \\
\text { cylinder }(\mathrm{m} 2)\end{array}$ & $A_{1}$ & $400 / 104$ \\
\hline $\begin{array}{l}\text { Average heat transfer area in } \\
\text { cold volume of the displacer } \\
\text { cylinder }(\mathrm{m} 2)\end{array}$ & $A_{27}$ & $400 / 104$ \\
\hline $\begin{array}{l}\text { Average heat transfer area in } \\
\text { expansion volume }(\mathrm{m} 2)\end{array}$ & $A_{28}$ & $400 / 104$ \\
\hline $\begin{array}{l}\text { Tube diameter in heater and } \\
\text { cooler }(\mathrm{m})\end{array}$ & & 0.002 \\
\hline $\begin{array}{l}\text { Heat transfer area of } \\
\text { regenerator cells }(\mathrm{m} 2)\end{array}$ & $A_{k}$ & 0.2 \\
\hline $\begin{array}{l}\text { Dead volumes in regenerator } \\
\text { cells (m3) }\end{array}$ & $V_{k}$ & $16.5 / 106$ \\
\hline Porosity of regenerator matrix & & $\% 75$ \\
\hline $\begin{array}{l}\text { Total volume of the IC Engine } \\
\text { (m3) }\end{array}$ & & $3200 / 106$ \\
\hline Power of the IC Engine $(\mathrm{kW})$ & & 120 \\
\hline
\end{tabular}

pressure of the Stirling engine exceeds the gas pressure of the IC engine, then some air leaks from the expansion volume of the Stirling engine into the operation volume of the IC engine. This is a periodically repeating phenomenon at each cycle of the IC engine. Due to this phenomenon, at steady running conditions, the average gas pressures in the IC and Stirling engines are expected to converge to each other. In modern turbocharged Diesel engines, at economic running conditions, the time average of the gas pressure in the cylinder is in the range of 10-15 bars (İpci and Karabulut, 2016). If the air mass in the Stirling engine is taken as $17 \mathrm{~g}$, then the average gas pressure in it becomes 12.65 bar. Therefore, $17 \mathrm{~g}$ air mass may be considered as the optimum working fluid mass for the Stirling part of the combined engine. Since the crosscut area of the piston rod is small enough compared to the crosscut area of the piston crown, the swept volumes of both engines are almost equal to each other. If we consider a Diesel type IC Engine with $800 \mathrm{cc}$ swept volume per cylinder and 2 bar charging pressure, the air mass taken into the cylinder per cycle becomes $1.66 \mathrm{~g}$. At economic running conditions of the Diesel engines, the practical air/fuel ratio is about 16 . The combustion heat of diesel fuel is give as about $42-46 \mathrm{MJ} / \mathrm{kg}$. If the combustion heat of diesel fuel is taken to be $44 \mathrm{MJ} / \mathrm{kg}$, the heat release in a cylinder per cycle is determined as about $4650 \mathrm{~J}$. From this value, by considering the statistical thermal efficiency of Diesel engines as \%33, the heat wasted with exhaust gas per cycle is estimated as $1500 \mathrm{~J}$. The other point is that, the IC engine performs one cycle within two revolutions and generate one times work while the Stirling engine is generating two times work. Considering this situation, the available heat for Stirling component of the combined engine is determined as $750 \mathrm{~J}$ for each cycle. Considering the statistical performance parameters of Diesel engines, for a Diesel engine running with $250 \mathrm{rad} / \mathrm{s}$ speed and consuming 4650 $\mathrm{J}$ heat per cycle, the power is estimated to be $30 \mathrm{~kW}$. In case of a Diesel engine with 4 cylinders, the power becomes $120 \mathrm{~kW}$.

Figure 4 indicates P-V diagram of the Stirling engine obtained for $17 \mathrm{~g}$ working fluid mass and $250 \mathrm{rad} / \mathrm{s}$ engine speed. The temperatures of hater and cooler surfaces were taken to be 800 and $392 \mathrm{~K}$ respectively. The heat transfer areas in heater and cooler were set as 0.6 and $0.33 \mathrm{~m} 2$. From P-V diagram, the minimum and maximum values of the engine inner volume are determined as 1.7922 and 2.5729 liter respectively. The compression ratio and mean gas pressure in the engine are determined to be 1.435 and 12.65 bar respectively. The cyclic heat received from heater by the working air and the work generated are $328 \mathrm{~J}$ and $150.97 \mathrm{~J}$ respectively. Considering $150.97 \mathrm{~J}$ cyclic work and 250 $\mathrm{rad} / \mathrm{s}$ speed, the power generation of a 4 cylinder Stirling engine is estimated to be $24 \mathrm{~kW}$. The total power of a combined Stirling-IC engine is estimated to be $144 \mathrm{~kW}$. For the same combined engine, the heat consumption per second is determined to be $370 \mathrm{~kW}$. The thermal efficiency is estimated as $39 \%$. The thermal efficiency of the stand-alone Diesel engine is $32.4 \%$. From these results, the increase of the thermal efficiency is estimated to be $6.6 \%$. This amount of increase of the thermal efficiency is almost equivalent to that provided by the 
Organic Rankin Cycle Vapor System. The ratio of increase of thermal efficiency to the thermal efficiency of the stand-alone engine becomes $20.37 \%$.

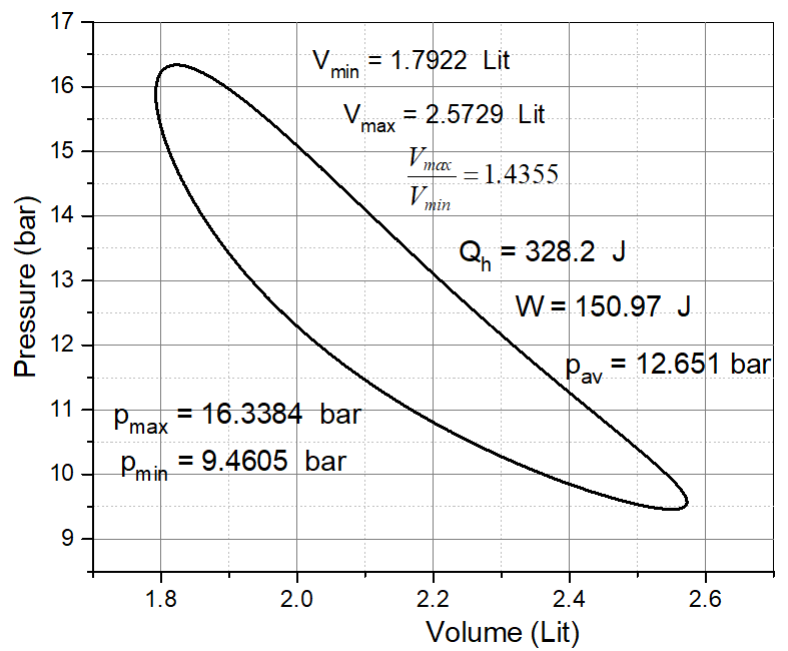

Figure 4. P-V diagram obtained for $17 \mathrm{~g}$ working fluid and $250 \mathrm{rad} / \mathrm{s}$ speed.

Via using the prepared simulation program, the variations of the thermodynamic performance parameters of the engine were examined with respect to the working gas mass. In this examination, in order to ensure the correct calculation of the thermal efficiency, the heat transfer area of the cooler was set to some appropriate values reducing the cyclic regenerator heat to small enough values. The heater area was kept constant as $0.6 \mathrm{~m} 2$. The temperatures of cooler and heater were taken to be 392 and $800 \mathrm{~K}$ respectively. The speed of the engine was set to $250 \mathrm{rad} / \mathrm{s}$. The gas mass in the engine was increased from $7 \mathrm{~g}$ to $21 \mathrm{~g}$ with $2 \mathrm{~g}$ increments. Table 2 and Figure 5 presents the results of this examination. Data presented in Table 2 and in Figure 5 were obtained after 720 cycles running of the engine. In this examination the time steps were taken to be 0.00002 second.

The second column of the Table 2 contains the heat received by the working fluid from the heat transfer surface of the heater. As seen from Figure 5, the heat received by the gas displays a slightly decelerating increase with working fluid mass but it is almost linear. The deceleration of increase of the heat is probably caused by limited heat transfer area in the heater. As seen from Table 2, when the air mass is $17 \mathrm{~g}$, the heat requirement of the engine is $328.2 \mathrm{~J}$ per cycle. This is lesser than the half of heat availability of the exhaust gas which was estimated in above paragraph as $750 \mathrm{~J}$ for each cycle of Stirling engine. This situation indicates that the heat required to energize the Stirling engine would be easily recovered from the exhaust gas of the IC Engine. The heat exchanger to be used for this purpose will not be a very complicated device.

The third column of Table 2 presents the unbalanced regenerator heat. The unbalanced regenerator heat is a residual heat appearing in energy balance of regenerator. The unbalance regenerator heat may be a positive or a negative magnitude. There are two causes of the unbalanced regenerator heat as; transient running of the engine and the absence of an energy balance equation in the analysis for regenerator matrix. In reality, at steady running conditions of a real engine, the heat given to the regenerator and taken from the regenerator all over the cycle should be in a balance. However, when an engine is set to run, for a period of time, it operates at transient conditions. After a period of time, the steady running conditions are reached. The simulation program prepared in this study works similar to the operation of the real engine. At transient running period of the simulation program, the heat given to the regenerator and taken from the regenerator is not in balance and the unbalanced heat decreases from cycle to cycle. When the simulation program is running, after a certain number of cycles, the unbalanced heat converges to a certain value. This remaining value of the unbalanced heat is caused by the absence of an energy balance equation in the analysis for regenerator matrix. In order to eliminate or minimize the remaining unbalanced regenerator heat, some appropriate values are introduced for heater and cooler areas. Data seen in Table 2 were obtained after 720 cycle running of the engine. The appropriate values of the cooler area are seen in last column of the Table 2. As seen from the Table, the unbalanced heat is small enough compared to the heat received from the heater.

In Table 2, the forth column presents the work generated by the Stirling engine per cycle. As seen from Figure 5, the work displays a decelerating increase with air mass. The variation of work with air mass is consistent with expectations. Deceleration of increase of work with air mass is caused by contraction of the temperature interval between temperature limits of the cycle. The fifth column of the Table 2 presents the thermal efficiency. Thermal efficiency was calculated by dividing the cyclic work with cyclic heat. As seen in Figure 5, while the air mass is increasing, the thermal efficiency displays an accelerating decrease. This is again due to contraction of the temperature interval between temperature limits of the cycle. In heater, regenerator and cooler, if there were large enough heat transfer surfaces and heat transfer coefficients, then, the lowest and highest temperature limits of the cycle will be equal to the cooler and heater temperatures respectively and, the thermal efficiency of the cycle will be equal to the Carnot efficiency. However, this is practically not possible. While the heat transfer areas are increasing, the dead volumes increase as well. A higher dead volume reduces the compression ratio of the engine and causes the work to decrease. If the regenerator is not perfect, the dead volume has also a negative effect on thermal efficiency. Therefore, the heat transfer areas of the heat exchange components of the Stirling engine may not be increased arbitrarily. In this examination, the heat transfer coefficient in regenerator was taken from Tanaka and coworkers (Tanaka et al, 1990) as $800 \mathrm{~W} / \mathrm{m}^{2} \mathrm{~K}$. The heat transfer coefficient in cooler, heater and other heat transfer surfaces were taken as $300 \mathrm{~W} / \mathrm{m}^{2} \mathrm{~K}$ which is a reasonable value to enable. The heat transfer areas of regenerator and heater were taken 
as $4.6 \mathrm{~m} 2$ and $0.6 \mathrm{~m} 2$ respectively. The cooler area varies from $0.23 \mathrm{~m} 2$ to $0.37 \mathrm{~m} 2$. For $17 \mathrm{~g}$ air mass the cooler area was determined as $0.3325 \mathrm{~m} 2$. As seen from Figure 5 , the curve of the thermal efficiency has a maximum at $7 \mathrm{~g}$ air mass. The maximum thermal efficiency appearing at $7 \mathrm{~g}$ air mass is $51.76 \%$. Considering $392 \mathrm{~K}$ cooler temperature and $800 \mathrm{~K}$ heater temperature, the Carnot efficiency of the cycle is determined to be $51 \%$. The thermal efficiency calculated via this simulation exceeds the Carnot efficiency as $0.76 \%$. This is a numerical error related to the time step used in the simulation which is 0.00002 second.

The sixth column in Table 2 presents the power of the engine. As seen from Figure 5, the power displays a decelerating increase with air mass. After a certain value of air mass, the power will tend to decrease. The maximum value of the power is $6576 \mathrm{~W}$ and corresponds to $21 \mathrm{~g}$ air mass. For $21 \mathrm{~g}$ air mass, the average pressure of the cycle becomes 15.48 bar. This pressure is above the average cylinder pressure of Diesel engines and therefore, it may not be considered as the optimum value of the average pressure of the Stirling engine. In Table 2, the seventh column presents the average pressure of cycles. As seen from Figure 5, the average pressure exhibits a linear variation with air mass which is an inherent result.

Via using the prepared simulation program, the variations of the thermodynamic performance parameters of the engine were examined with respect to the speed as well. In this examination, the mass of working gas in the engine was taken to be $17 \mathrm{~g}$. The cooler and heater temperature were taken as 392 and $800 \mathrm{~K}$ respectively. The heat transfer area of the heater was set to $0.6 \mathrm{~m} 2$. The heat transfer area of the cooler was set to some appropriate values to minimize the cyclic regenerator heat. The speed was varied from $100 \mathrm{rad} / \mathrm{s}$ to $300 \mathrm{rad} / \mathrm{s}$ with $25 \mathrm{rad} / \mathrm{s}$ increments.

Results obtained from this examination were presented in Table 3 and in Figure 6. In this examination the time steps were taken to be 0.00002 second as well. Data presented in Table 3 and in Figure 6 were obtained after different amount of running periods ranging from 1400 to 2200 cycles. At higher values of speed, higher number of cycles were needed to obtain stable results.

The second column in Table 3 indicates the heat exchange between heater and working air of the engine. As seen from Figure 6, the heat exhibits a decelerating decrease with engine speed. The maximum heat exchange appears at about $100 \mathrm{rad} / \mathrm{s}$ speed as $379 \mathrm{~J}$ per cycle. The minimum value of the heat exchange appears at $300 \mathrm{rad} / \mathrm{s}$ speed as $315.5 \mathrm{~J}$ per cycle. While speed is increasing the decrease of heat exchange is an inherent situation because of that the heat exchange is proportional with time.

Table 2. Variations of thermodynamic parameters with air mass.

\begin{tabular}{|c|c|c|c|c|c|c|c|}
\hline $\begin{array}{c}\text { Air mass } \\
(\mathrm{g})\end{array}$ & $\begin{array}{c}\text { Heat } \\
(\mathrm{J})\end{array}$ & $\begin{array}{c}\text { Unbalanced } \\
\text { heat in Reg. }(\mathrm{J})\end{array}$ & $\begin{array}{c}\text { Work } \\
(\mathrm{J})\end{array}$ & $\begin{array}{c}\text { Thermal } \\
\text { efficiency }(\%)\end{array}$ & $\begin{array}{c}\text { Power } \\
(\mathrm{W})\end{array}$ & $\begin{array}{c}\text { Average } \\
\text { pressure }(\text { bar })\end{array}$ & $\begin{array}{c}\text { Cooler area } \\
(\mathrm{m} 2)\end{array}$ \\
\hline 5 & 117.22 & -3.85 & 59.66 & 50.89 & 2373.82 & 3.79180 & 0.2275 \\
\hline 7 & 155.31 & -2.26 & 80.40 & 51.76 & 3199.15 & 5.29542 & 0.2450 \\
\hline 9 & 192.15 & -0.99 & 98.93 & 51.48 & 3936.41 & 6.78897 & 0.2625 \\
\hline 11 & 228.01 & -0.14 & 115.21 & 50.52 & 4584.16 & 8.27076 & 0.2800 \\
\hline 13 & 262.76 & 0.54 & 129.24 & 49.18 & 5142.5 & 9.73970 & 0.2975 \\
\hline 15 & 296.15 & 0.15 & 141.11 & 47.65 & 5614.82 & 11.19541 & 0.3150 \\
\hline 17 & 327.92 & 0.075 & 150.99 & 46.04 & 6007.58 & 12.63784 & 0.3325 \\
\hline 19 & 358.03 & 0.32 & 158.98 & 44.40 & 6325.78 & 14.06664 & 0.3500 \\
\hline 21 & 386.33 & -0.48 & 165.27 & 42.78 & 6576.05 & 15.48283 & 0.3675 \\
\hline
\end{tabular}

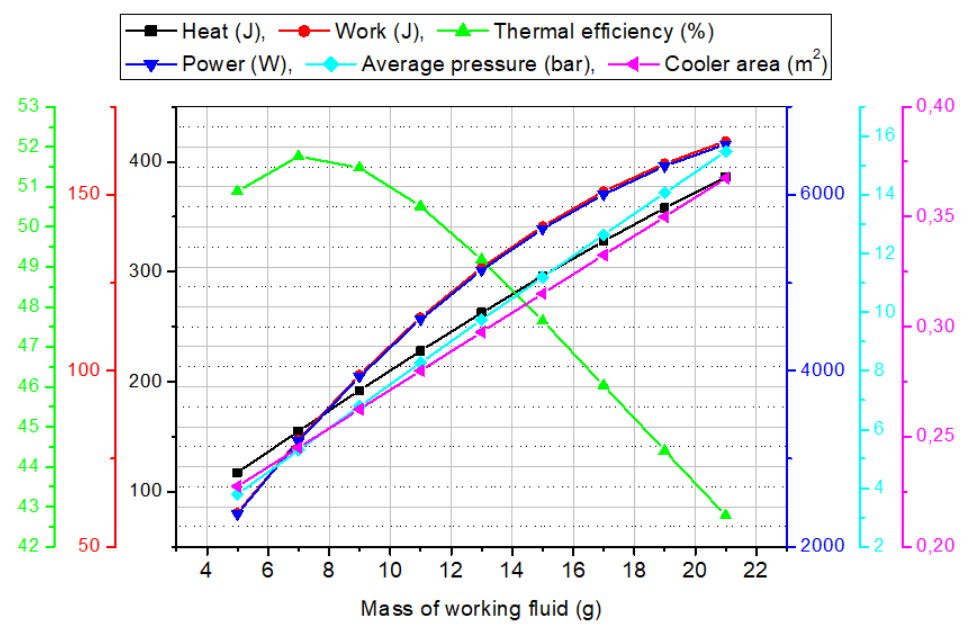

Figure 5. Variations of thermodynamic parameters with air mass. 
The highest value of the heat exchange is approximately $50 \%$ of the heat availability of the exhaust gas of the Diesel engine combined with the Stirling engine. This indicates that the heat exchanger to be used in the system will be not very complicated. The third column in Table 3 presents the unbalanced heat in regenerator. The unbalanced heat is small enough to influence the accuracy of the thermal efficiency except the one appearing at $100 \mathrm{rad} / \mathrm{s}$ speed. To get correct data at very low values of the speed, very small time steps and very large amount of transient running periods are needed.

In Table 3, the column 4 and 5 indicate the variations of cyclic work and thermal efficiency with speed of the engine. As seen from Figure 6, the work displays a linearly decreasing tendency with speed. While speed increasing, the heat transfer time of the cycle decreases linearly. Proportionally with time, the heat exchange between working fluid and heat transfer surfaces of heater and cooler decreases as well. As the result of this, the work may present a linear decrease. As seen from Figure 6, the thermal efficiency presents an accelerating decrease with speed. While the work is presenting a linear decrease and heat is presenting a decelerating decrease, the thermal efficiency may present an accelerating decrease. Within the examined limits of speed, the minimum and maximum values of the thermal efficiency are $43.45 \%$ and $52.1 \%$ respectively. At 100 $\mathrm{rad} / \mathrm{s}$ speed, compared to the Carnot efficiency, there is $1.1 \%$ excess in the thermal efficiency of the nodal approximation conducted here.

As seen from Figure 6, the efficiency curve has a maximum at $100 \mathrm{rad} / \mathrm{speed}$ as well. This feature of the efficiency curve indicates that the thermal efficacy predicted by the nodal approximation involves at most $1.1 \%$ error. This error is caused by numerical error and unbalanced regenerative heat seen in the third column of the Table 3. For $250 \mathrm{rad} / \mathrm{s}$ speed, the thermal efficiency of the engine is $46.87 \%$ which is a trustable result from accuracy point of view.

The column 6 of the Table 3 contains the power of the Stirling engine. The power displays a decelerating increase with speed. The cause of increase of power with speeds is due to the increase of speed. The deceleration of increase of the power is caused by the decrease of work. For $250 \mathrm{rad} / \mathrm{s}$ speed, which was assumed to be the optimum value of it, the power is $6125 \mathrm{~W}$. Between 150 $\mathrm{rad} / \mathrm{s}$ and $275 \mathrm{rad} / \mathrm{s}$, which is the most common use range of speed in Diesel engines, the power varies from 4363 $\mathrm{W}$ to $6375 \mathrm{~W}$.

Considering that a four-cylinder Diesel engine will be combined with a four-cylinder Stirling engine, the power contribution of the Stirling engine to the combined system is determined as a quantity between $17.45 \mathrm{~kW}$ and $25.5 \mathrm{~kW}$. Where, the power of the stand-alone Diesel engine is about $120 \mathrm{~kW}$. This result indicates that a Hybrid engine consisting of a Diesel and a Stirling engine would be more advantageous than Diesel-ORC combined systems.

In Table 3, column 7 presents the cyclic average values of the pressure in the engine. Its variation with speed is $2.5 \%$ which is not significant. Column 7 indicates the cooler area of the engine. While the speed is changing form $100 \mathrm{rad} / \mathrm{s}$ to $300 \mathrm{rad} / \mathrm{s}$ with $25 \mathrm{rad} / \mathrm{s}$ increments, the cooler area varies from $0.24 \mathrm{~m} 2$ to $0.36 \mathrm{~m} 2$ linearly with $0.015 \mathrm{~m} 2$ increments. The cooler area corresponding to $250 \mathrm{rad} / \mathrm{s}$ speed is $0.33 \mathrm{~m} 2$ and it seems to be an appropriate value for all working conditions of the engine.

Via using the prepared simulation program, the variations of the thermodynamic performance parameters of the engine were examined with respect to the heater temperature as well. In this examination, the mass of working gas in the engine, the heater area, and engine speed were taken to be $17 \mathrm{~g}, 0.6 \mathrm{~m} 2$ and $250 \mathrm{rad} / \mathrm{s}$ respectively. The regenerator heat was minimized again via setting appropriate values for cooler area. The heater temperature was varied from $700 \mathrm{~K}$ to $900 \mathrm{~K}$ with $25 \mathrm{~K}$ increments. Table 4 and Figure 7 indicate results of this examination. In this examination, the time steps were taken to be 0.00002 second as well. Data presented in Table 4 and in Figure 7 were obtained after 1400 cycle running period of the engine.

Table 3. Variations of thermodynamic parameters with engine speed.

\begin{tabular}{|c|c|c|c|c|c|c|c|}
\hline $\begin{array}{c}\text { Engine speed } \\
(\mathrm{rad} / \mathrm{s})\end{array}$ & $\begin{array}{c}\text { Heat } \\
(\mathrm{J})\end{array}$ & $\begin{array}{c}\text { Unbalanced } \\
\text { heat in Reg. }(\mathrm{J})\end{array}$ & $\begin{array}{c}\text { Work } \\
(\mathrm{J})\end{array}$ & $\begin{array}{c}\text { Thermal } \\
\text { efficiency (\%) }\end{array}$ & $\begin{array}{c}\text { Power } \\
(\mathrm{W})\end{array}$ & $\begin{array}{c}\text { Average } \\
\text { pressure (bar) }\end{array}$ & $\begin{array}{c}\text { Cooler area } \\
(\mathrm{m} 2)\end{array}$ \\
\hline 100 & 379.22 & -6.73 & 197.6 & 52.1 & 3144.6 & 12.88420 & 2400 \\
\hline 125 & 366.51 & -2.9 & 190.43 & 51.96 & 3788.66 & 12.85334 & 2550 \\
\hline 150 & 356.75 & -1.54 & 182.76 & 51.22 & 4363.06 & 12.81727 & 2700 \\
\hline 175 & 348.75 & -0.68 & 175.32 & 50.26 & 4882.94 & 12.78096 & 2850 \\
\hline 200 & 341.44 & 0.78 & 169.12 & 49.53 & 5383.42 & 12.73767 & 3000 \\
\hline 225 & 335.03 & -0.76 & 160.56 & 47.92 & 5749.72 & 12.69786 & 3150 \\
\hline 250 & 328.38 & -0.04 & 153.92 & 46.87 & 6124.66 & 12.65159 & 3300 \\
\hline 275 & 321.91 & 0.08 & 145.66 & 45.25 & 6375.23 & 12.60962 & 3450 \\
\hline 300 & 315.52 & -0.48 & 137.12 & 43.45 & 6546.91 & 12.56580 & 3600 \\
\hline
\end{tabular}




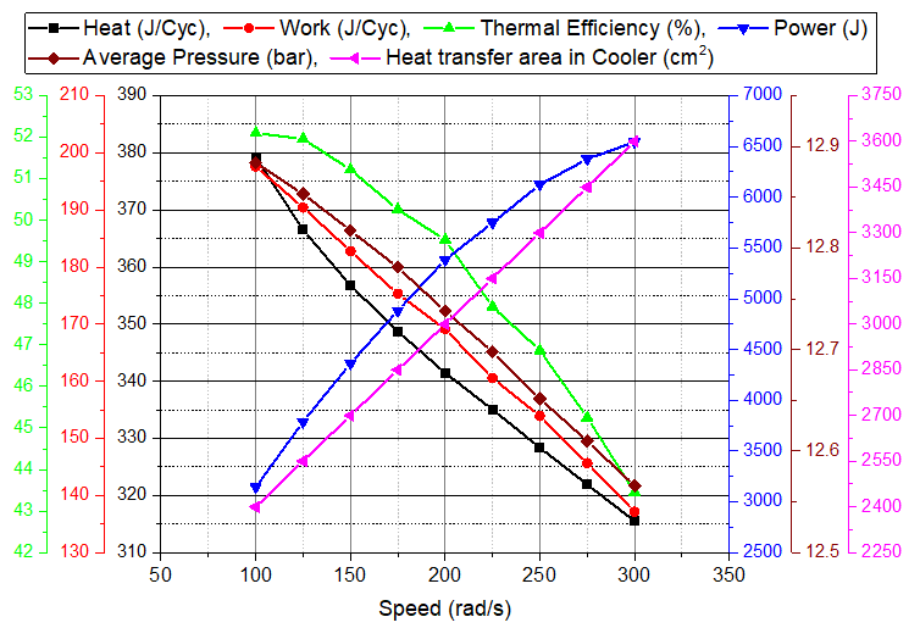

Figure 6. Variations of thermodynamic parameters with engine speed.

As seen from Figure 7, all of the thermodynamic parameters are varying linearly with heater temperature except thermal efficiency. The thermal efficiency displays a decelerating increase. The deceleration of the increase of the thermal efficiency may be due to downward variation of cooler area. If the efficiency of the heat exchanger recovering waste heat from exhaust gas is assumed to be $50 \%$, which is a plausible value, the heat provided by this exchanger would be
$750 \times 0.5=375 \mathrm{~J}$ per cycle of Stirling engine. From Table 4 , corresponding to $375 \mathrm{~J}$ heat, a heater temperature of $876 \mathrm{~K}$ is seen. This result indicates that the heater temperature could be increased up to $875 \mathrm{~K}$. As the result of this increase, the power provided by a 4 cylinder Stirling engine could increase up to $29 \mathrm{~kW}$.

Table 5. Variations of thermodynamic parameters with heater temperature.

\begin{tabular}{|c|c|c|c|c|c|c|c|}
\hline $\begin{array}{c}\text { Heater } \\
\text { temperature }(\mathrm{K})\end{array}$ & $\begin{array}{c}\text { Heat } \\
(\mathrm{J})\end{array}$ & $\begin{array}{c}\text { Unbalanced } \\
\text { heat in Reg. (J) }\end{array}$ & $\begin{array}{c}\text { Work } \\
(\mathrm{J})\end{array}$ & $\begin{array}{c}\text { Thermal } \\
\text { efficiency (\%) }\end{array}$ & $\begin{array}{c}\text { Power } \\
(\mathrm{W})\end{array}$ & $\begin{array}{c}\text { Average } \\
\text { pressure (bar) }\end{array}$ & $\begin{array}{c}\text { Cooler area } \\
(\mathrm{cm} 2)\end{array}$ \\
\hline 700 & 263.71 & -4.48 & 107.24 & 40.66 & 4267.18 & 11.65819 & 0.3825 \\
\hline 725 & 279.73 & -3.18 & 118.17 & 42.24 & 4701.87 & 11.90121 & 0.3700 \\
\hline 750 & 295.74 & -2.01 & 129.1 & 43.65 & 5136.85 & 12.14533 & 0.3575 \\
\hline 775 & 311.83 & -0.51 & 140.04 & 44.90 & 5571.9 & 12.39056 & 0.3450 \\
\hline 800 & 327.91 & -0.19 & 150.98 & 46.04 & 6007.5 & 12.63782 & 0.3325 \\
\hline 825 & 344.08 & 0.46 & 161.93 & 47.06 & 6443.0 & 12.88678 & 0.3200 \\
\hline 850 & 360.24 & -0.12 & 172.91 & 48.0 & 6879.88 & 13.13847 & 0.3075 \\
\hline 875 & 376.59 & -0.11 & 183.88 & 48.83 & 7316.45 & 13.39230 & 0.2950 \\
\hline 900 & 392.03 & 0.19 & 194.66 & 49.65 & 7745.47 & 13.62060 & 0.2825 \\
\hline
\end{tabular}

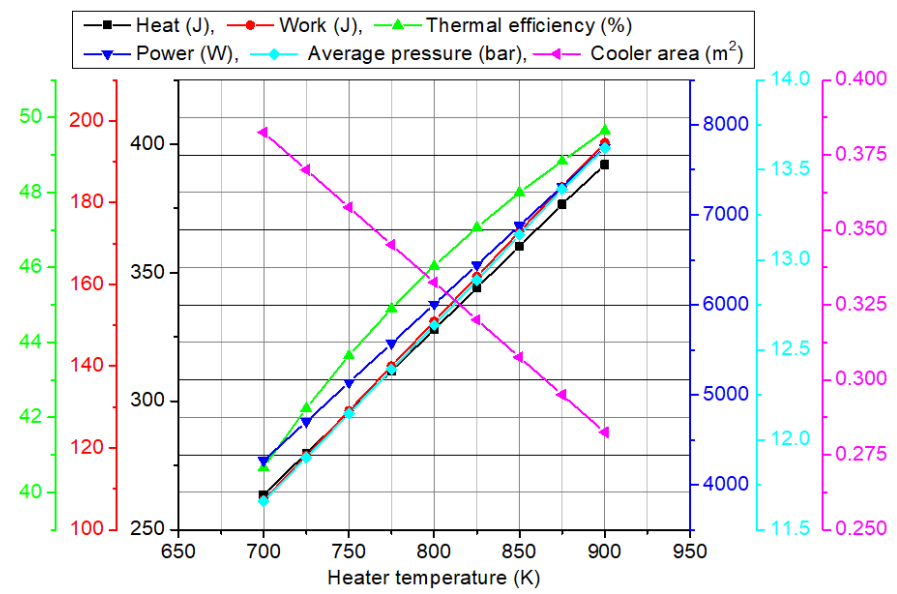

Figure 7. Variations of thermodynamic parameters with heater temperature. 


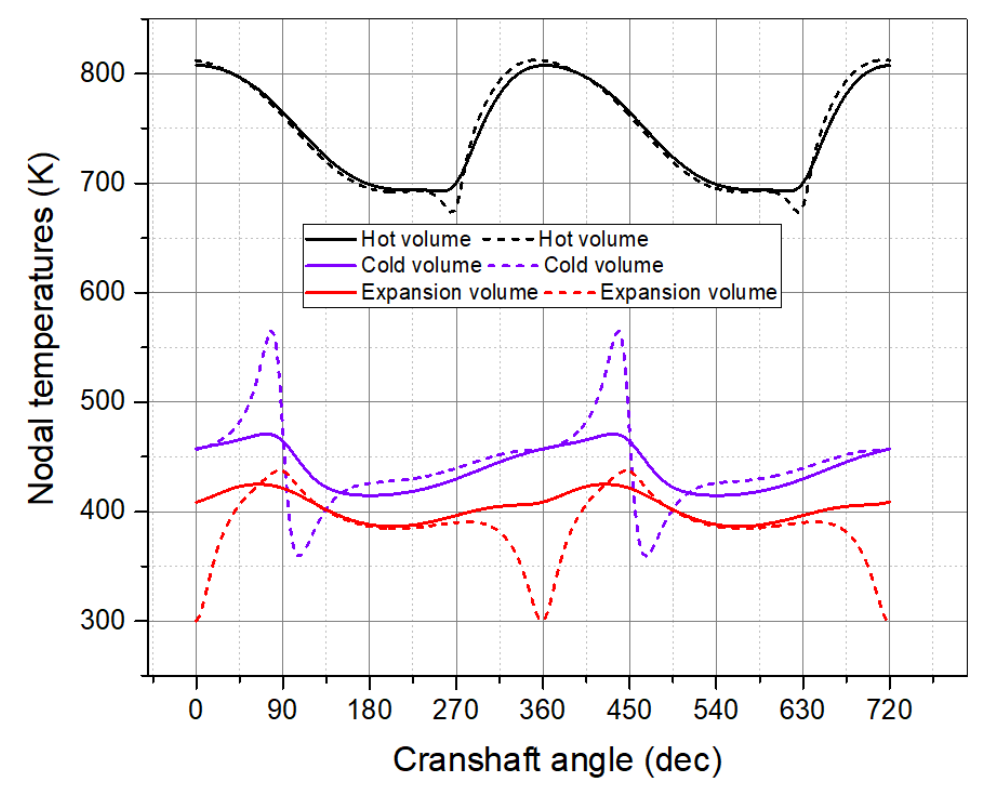

Figure 8. Temperature variations in hot, cold and expansion volumes

Figure 8 indicates variations of gas temperatures in hot volume, cold volume and expansion volumes. In the case of that zero dead volume is left in hot, cold and expansion spaces of the engine, the minimum values of mass in that spaces tends to go zero. Due to these tendencies of masses in that volumes, some unrealistic temperature profiles, as indicated with dashed lines in Figure 8, appears. If a little clearance is left between displacer top and displacer cylinder top, displacer bottom and displacer cylinder bottom and, piston bottom and expansion cylinder bottom; than realistic forms of temperature profiles are obtained as indicated with continuum lines in Figure 8. In practice also its necessary to left some little dead volumes in hot, cold and expansion volumes. As seen from Figure 8, the average temperature in expansion volume is about $400 \mathrm{~K}$. At $400 \mathrm{~K}$, the lubricant is not expected to evaporate. As seen from Figure 8 the average temperature in cold volume of displacer cylinder is less than $450 \mathrm{~K}$. It is seen that, even in cold volume of displacer cylinder the temperature is not as high as to evaporate lubricant. As the result of these examination the cold end connection of displacer cylinder to expansion cylinder is seen as a useful strategy to protect the heat exchangers from lubricant contamination.

\section{CONCLUSION}

This study indicated that, if a Gamma Type Stirling engine is combined with a Diesel engine, the thermal efficiency of the combined system will increase more than $6 \%$ compared to the stand-alone Diesel engine. The Stirling engine could use the gas leaking from operation chamber of the Diesel engine as working fluid and no additional compressor will be used to charge the working gas into the Stirling engine. A Stirling engine combined with a $120 \mathrm{~kW}$ Diesel engine could produce a power more than $24 \mathrm{~kW}$. The heater, regenerator and cooler areas of the Stirling engine were optimized as about 0.6, 4.6 and $0.33 \mathrm{~m} 2$ respectively. The optimum value of working air in Stirling engine was determined as $17 \mathrm{~g}$.
Cold and connection of displacer cylinder to expansion cylinder was found to be a useful strategy to avoid the evaporation of lubricant and to protect the contamination of heat exchangers.

\section{REFERENCES}

Alfarawi S., Martin M.W., Mahmoud S. and Aldadah R.K., 2014, Thermal Analysis of Stirling Engine to Power Automotive Alternator Using Heat from Exhaust Gases, Energy Procedia, 61, 2395-2398. doi:10.1016/j.egypro.2014.12.013

Cullen B., McGovern J., Feidt M. and Petrescu S., 2009, Preliminary Modelling Results for an Otto Cycle/Stirling Cycle Hybrid-engine-based Power Generation System, 22nd International Conference on Efficiency, Cost, Optimization Simulation and Environmental Impact of Energy Systems (ECOS), Brazil, 2091-2100.

Hirata K. and Kwada M., 2005, Discussion of Marine Stirling Engine Systems, Proceedings of the 7th International Symposium on Marine Engineering, Tokyo.

Huang Y., Gao W. and Li G., 2016, Simulation And Experimental Study of The Otto and Stirling Combined Cycle, Journal of Renewable and Sustainable Energy, 8(3), 1-13. doi.org/10.1063/1.4948374

Ipci D. and Karabulut H., 2016, Thermodynamic and Dynamic Modeling of a Single Cylinder Four Stroke Diesel Engine, Applied Mathematical Modelling, 40 (56), 3925-3937. doi.org/10.1016/j.apm.2015.10.046

Izadiamoli N. and Sayyaadi H., 2018, Conceptual Design, Optimization and Assessment of a Hybrid OttoStirling Engine/Cooler for Recovering the Thermal Energy of the Exhaust Gasses for Automotive Applications, Energy Conversion and Management, 171, 1063-1082. doi.org/10.1016/j.enconman.2018.06.056 
Jadhao J.S. and Thombare D.G., 2013, Review on Exhaust Gas Heat Recovery for IC Engine, International Journal of Engineering and Innovative Technology (IJEIT), 2(12), 96-100.

Karabulut H., Okur M. and Ozdemir A.O., 2019, Performance Prediction of a Martini Type of Stirling Engine, Energy Conversion and Management, 179, 1-12. doi: 10.1016/j.enconman. 2018.10.059

Li T., Tang D.W., Li Z., Du J., Zhou T. and Jia Y., 2012, Development and Test of a Stirling Engine Driven by Waste Gases for the Micro-CHP System, Applied Thermal Engineering, 33-34, 119-123. doi.org/10.1016/j.applthermaleng.2011.09.020

Noor A.M., Puteh R.C. and Srithar Rajoo S., 2014, Waste Heat Recovery Technologies in Turbocharged Automotive Engine - A Review, Journal of Modern Science and Technology, 2(1), 108-119.
Saxena S. and Ahmed M., 2017, Automobile Exhaust Gas Heat Energy Recovery Using Stirling Engine: Thermodynamic Model, SAE Technical Paper, 2017-260029 .

Tanaka M., Yamashita I. and Chisaka F., 1990, Flow and Heat Transfer Characteristics of the Stirling Engine Regenerator in an Oscillating Flow, JSME International Journal, 33(2), 283-289. doi:10.1299/jsmeb1988.33.2_283

Wang K., Sanders S.R., Dubey S., Choo F.H. and Duan F., 2016, Stirling Cycle Engines for Recovering Low and Moderate Temperature Heat: A Review, Renewable and Sustainable Energy Reviews, 62, 89-108. doi:10.1016/j.rser.2016.04.031

Yu Y., Yuan Z., Ma J. and Li S., 2013, Design and Simulation of Exhaust Gas Waste Heat Recovery System of Gasoline Engine Based on Stirling Cycle, IEEE, 9781-4799-3336, 855-859.
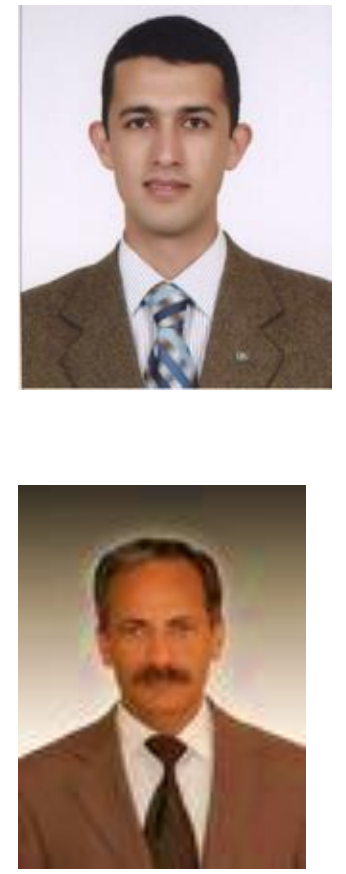

Mesut DÜZGÜN is currently a lecturer of Automotive Engineering Department at the Gazi University, which he joined in 2002. He received his first B.E. in Automotive Education Department in 2000, from Gazi University in Turkey. He graduated from the Gazi University with Graduate School of Natural and Applied Sciences an M.Sc. in 2002 and received his Ph.D. degree; in 2008 to Gazi University. After working for 2 years in the Republic of Turkey Ministry of National Education, he joined the Gazi University as a Research Assistant Automotive Department in 2002. He became an Assistant Professor in the same department in 2009 and he became an Associate Professor in 2017. His current research areas are Vehicle Dynamics, Vehicle Technology and Engine Technologies. He is specialized in the field of brake systems and applications. He has worked on some projects in vehicle technology area and as researcher in numerous international projects in Turkey.

Halit KARABULUT was born in 1959 in Antalya. He graduated from the Higher Technical Teachers Academy in 1980. In 1987, he completed his master's degree at the Mechanical Education Department, Institute of Science, Gazi University. He completed his Ph.D. at HeriotWatt University in 1991. In 1992, he was appointed as Assistant Professor at Technical Education Faculty, Gazi University. In 1997, he became an Associate Professor at the Technical Education Faculty of Gazi University. In 2000, he was assigned as an Associate Professor at Akdeniz University. In 2003, he became a Professor at the Technical Education Faculty, Gazi University. He has been working as a Professor at Automotive Engineering Department of Technology Faculty at Gazi University, since 2011. 